\title{
Molecular Virology of Hepatitis B Virus and Targets for Antiviral Intervention
}

\author{
Dieter Glebe Alexander König \\ Institute of Medical Virology, Justus Liebig University Giessen, National Reference Center for Hepatitis B and D \\ Viruses, German Center for Infection Research (DZIF), Biomedical Research Center Seltersberg, Giessen, Germany
}

\author{
Key Words \\ Hepatitis B virus · Antiviral therapy · Replication · Covalently \\ closed circular DNA
}

\begin{abstract}
The members of the viral family Hepadnaviridae comprise one of the smallest enveloped DNA viruses and cause acute and chronic infections in mammals and birds, leading to large virus and antigen loads in the blood. They have a restricted host range and depend on differentiated hepatocytes for replication. Hepatitis B virus (HBV) is the prototype of the Hepadnaviridae. HBV can persist in infected hepatocytes and has evolved elaborate strategies to evade the immune system. HBV replicates like HIV (family of Retroviridae) via reverse transcription. Drugs licensed for inhibition of HIV reverse transcriptase lower the viral load of chronic HBV patients, but they do not cure the infection. HBV genomes are archived in the nucleus of hepatocytes as episomal DNA before reverse transcription. In contrast, the RNA genome of HIV first needs reverse transcription before proviral integration within the host genome. Wild-type HBV remains relatively stable in chronic HBV patients during the immunotolerant state, but is able to evolve mutants rapidly upon selective pressure due to therapy or immune reactions. Current therapies for chronic hepatitis B are far from optimal. To extend therapeutic options, further studies on HBV and its interaction with the host are urgently needed.
\end{abstract}

(c) 2014 S. Karger AG, Basel

\section{KARGER}

(C) 2014 S. Karger AG, Basel

0300-5526/14/0574-0134\$39.50/0

E-Mail karger@karger.com

www.karger.com/int

\section{Introduction}

Hepatitis B, caused by infection with hepatitis B virus (HBV), is an infectious disease that is still one of the major global health problems. HBV infection can lead to acute and chronic liver disease. Worldwide, more than 240 million people are currently chronic HBV carriers [1], and more than 620,000 die annually from the longterm sequelae of this disease, despite the fact that the infection is preventable by a protective vaccine that has been available worldwide for over 25 years [2]. Vaccination can especially protect newborns from one of the major natural transmission routes that keep this bloodborne virus within the human community: vertical transmission from chronic HBV-infected mother to the child at birth. Infection during birth or early childhood results in $90 \%$ of the cases developing into a chronic carrier state. Chronic HBV infection may proceed after decades of seemingly good health in approximately $20-30 \%$ of the virus carriers to liver fibrosis, cirrhosis, and hepatocellular carcinoma. Progression depends on ongoing viral replication [3]. Careful monitoring of the 240 million chronic HBV-infected persons worldwide and successful treatment of the roughly 60 million with active replication is therefore the main goal of antiviral therapy. Understanding the molecular virology of $\mathrm{HBV}$, including its close interconnection during replication with hepatocytes and the immune system, will provide opportunities for devel-

Dieter Glebe

Institute of Medical Virology, National Reference Centre for Hepatitis B and D Viruses Justus-Liebig University of Giessen

Schubert-Strasse 81, DE-35392 Giessen (Germany)

E-Mail dieter.glebe@viro.med.uni-giessen.de 
opment of better therapies and vaccines. In this review we describe basic virological aspects of the viral replication cycle with special consideration of current and innovative therapies of chronic hepatitis $B$.

\section{Classification of HBV}

HBV belongs to the family of Hepadnaviridae, a family of small enveloped viruses. All Hepadnaviridae are able to cause acute and persistent infections with viremia and antigenemia. Strong hepatotropism combined with relatively strict species specificity are further hallmarks of this viral family. The orthohepadnaviruses of the mammals comprise the species HBV with many genotypes in humans and apes (gorillas, chimpanzees, gibbons, and orangutans) [4]. Another primate orthohepadnavirus species (WMHBV) has been isolated from a New World 'woolly monkey' [5]. For long time, the family of Sciuridae (esp. 'Northern American squirrels', e.g. woodchuck, ground squirrel, and arctic squirrel) were the only additional animal hosts for mammalian orthohepadnaviruses. In 2013, however, we [6] and another group [7] isolated new hepadnaviruses in bats from Africa, Central America, and Asia. Interestingly, these batderived orthohepadnaviruses were phylogenetically very close to HBV genotype F and WMHBV, and have zoonotic potential [6]. For human HBV, at least 9 genotypes (10 genotypes A-J) have been characterized that differ in the nucleotide (nt) level of their genome by more than $8 \%$. The many subgenotypes differ by $4 \%$ [4]. For more information on HBV genotypes, see the review by Kramvis [this issue, pp. 141-150].

\section{Virion Structure}

HBV appears as a spherical particle under native conditions with an outer diameter of approximately $52 \mathrm{~nm}$ $[8,9]$. Three HBV surface proteins and lipids enclose the icosahedral nucleocapsid core, combining 240 core protein subunits that are around $36 \mathrm{~nm}$ in diameter. The nucleocapsid contains the viral DNA genome and several cellular proteins, e.g. protein kinases [10-12]. A hallmark of all Hepadnaviridae is the secretion of HBV surface proteins (for HBV HBsAg particles) as subviral particles in spherical or filamentous form (fig. 1). These particles do not contain viral DNA and are noninfectious. The second major viral antigen, the core protein, may also be secreted as the so-called 'e-antigen'. Both antigens are produced in

Molecular Virology of HBV and Targets

for Antiviral Intervention large excess and may reach up to hundred or more $\mu \mathrm{g} / \mathrm{ml}$ protein per $\mathrm{ml}$ serum.

\section{Genome Organization and Transcriptome}

The small genomes of Hepadnaviridae have a unique structure with a relaxed circular (rc), partially doublestranded DNA of 3.1-3.3 kb [13]. Circularization is achieved by base-pairing of an interconnected overlap between the $5^{\prime}$ ends of the plus and minus strand DNA. The two DNA strands still carry their primers from the replication. The $5^{\prime}$ end of the minus strand is covalently linked to a tyrosine hydroxyl residue in the terminal protein domain of the HBV polymerase. The $5^{\prime}$ end of the plus DNA strand is formed by a 19 -nt-long $5^{\prime}$-capped RNA remnant of the pregenomic RNA (pgRNA) [for review, see 14]. The circular HBV genome contains four overlapping open reading frames (ORFs):

(1) The longest ORF (Pol) covers around $70 \%$ of the viral genome and encodes the viral polymerase, a polyprotein comprising three subdomains: the reverse transcriptase including the DNA-dependent DNA polymerase for plus strand synthesis, the terminal protein domain priming the minus strand DNA synthesis, and the $\mathrm{RNase} \mathrm{H}$ located at the carboxy-terminus.

(2) The surface proteins (S-ORF), which code for three co-carboxy-terminal HBV surface (HBs) proteins: the large (LHBs), middle (MHBs), and small (SHBs) protein. The backbone of the surface proteins is the carboxy-terminal S-domain that is present in all three proteins. The amino-terminal preS1-domain is only present in LHBs [15]; preS2 is available in LHBs and MHBs [for review, see 16,17$]$.

(3) Precore/core encodes the structural core protein and an additional precore sequence. Full translation of precore/core ORF leads to synthesis and processing of $\mathrm{HBeAg}$ that can be regarded as a nonstructural form of the core proteins that is efficiently secreted $[18,19]$.

(4) The still enigmatic X protein, encoded by X-ORF, whose function is still not fully understood, is believed to be involved in the epigenetic control of $\mathrm{HBV}$ transcription and HBV-associated carcinogenesis [20, 21]. Phenotypically, all viral transcripts are similar to cellular mRNAs, with $5^{\prime}$ cap and $3^{\prime}$ polyadenylation; however, they are usually not spliced. Liver-specific expression of $\mathrm{HBV}$ is driven by at least four promoter and two enhancer elements containing binding sites for liver-specific but also ubiquitous transcription factors supporting the efficient transcription of HBV covalently closed circular DNA (cccDNA). 


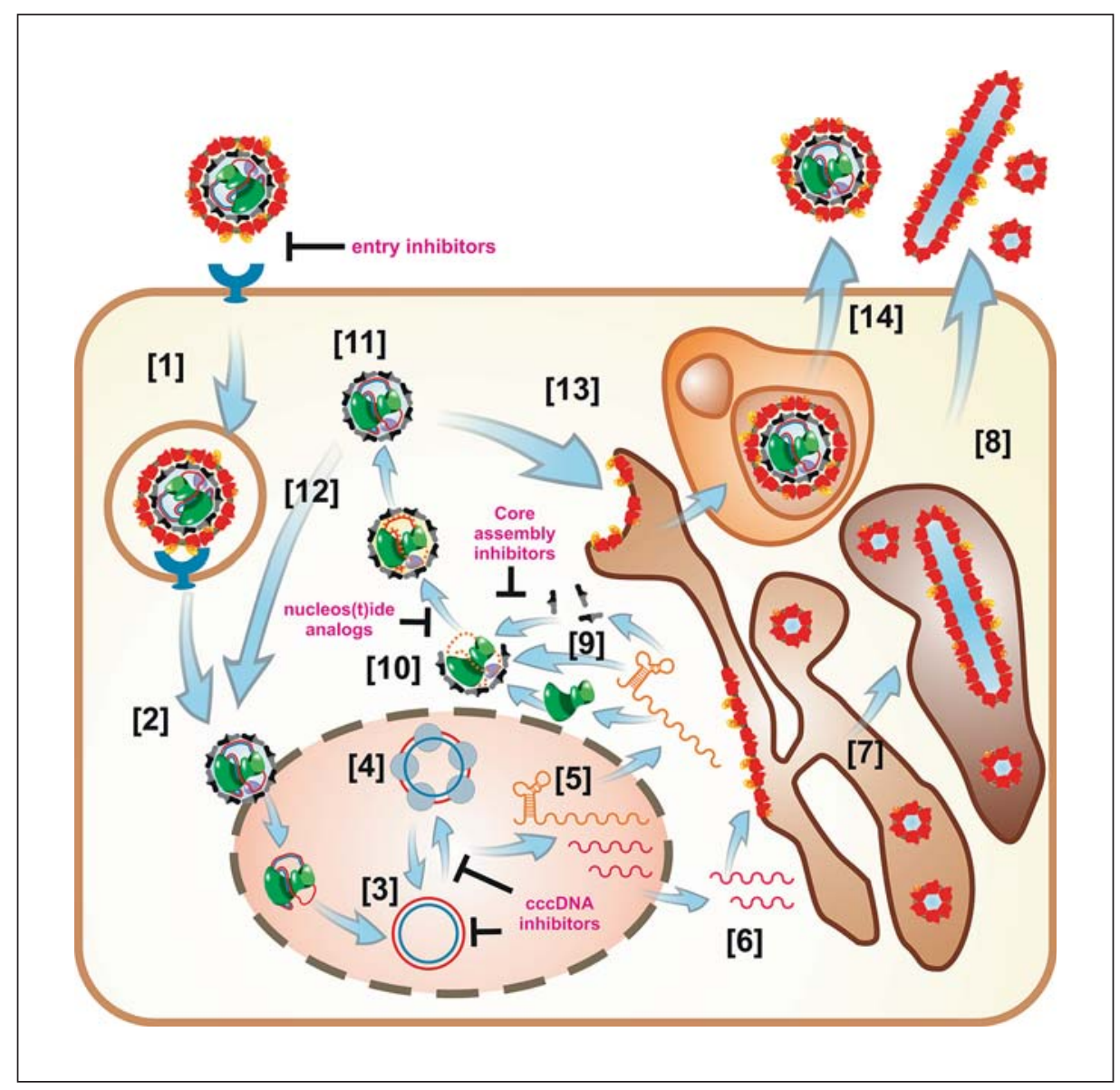

Fig. 1. The replicative cycle of HBV in hepatocytes. HBV binds to low-specific heparan sulfate proteoglycans and high-specific (NTCP) receptors on the plasma membrane of differentiated hepatocytes [1], resulting in uptake in endosomal structures. After the fusion with an intracellular membrane, the released nucleocapsid is actively transported within the cytosol to the nucleus [2]. Disassembly of core particles occurs within the nuclear pore complex, resulting in release of the partially double-stranded HBV DNA genome into the karyoplasma. The repair of $\mathrm{HBV}$ rcDNA into cccDNA is subsequently mediated by cellular factors [3]. Cellular histone and nonhistone proteins associate with episomal cccDNA, similar to host chromosomes, allowing epigenetic modification [4]. The cccDNA serves as a template for transcription of pregenomic and subgenomic mRNAs [5] that are actively translocated from the nucleus into the cytosol [6]. Translation of two subgenomic HBV mRNAs (preS/S mRNAs) at the ER leads to synthe- sis of the three HBV surface proteins, required for envelopment of mature core particles [13] and construction and secretion of subviral particles $[7,8]$. pgRNA (orange; with the characteristic $5^{\prime}$ epsilon signal structure indicated) is translated to core proteins and the polymerase [9] that assemble their own template (pgRNA) together with cellular proteins (protein kinases and heat shock proteins) into an immature core particle [10]. Here, reverse transcription and genome maturation starts and the mature core particle [11] is either translocated to the nucleus [12] to replenish the cccDNA pool [3, 4], or enveloped with HBV surface proteins [13] and secreted through multivesicular particles [14]. The constitutive secretory pathway, including the ER-Golgi complex, is the exit pathway of the subviral particles. Synthesis of nonstructural viral proteins $\mathrm{HBe}$ and $\mathrm{HBx}$ is not shown. Current and potential inhibitors of $\mathrm{HBV}$ replication are indicated. The figure is adapted from Glebe and Bremer [16].

\section{Replicative Cycle of HBV}

HBV infection of hepatocytes is mediated by lowspecific binding to heparan sulfate proteoglycans [2224], followed by high-specific binding to a hepatic bile acid transporter: sodium-taurocholate cotransporting polypeptide (NTCP) [25]. After uptake in an endosomal compartment that has yet to be characterized, viral envelope proteins are believed to induce fusion of the viral and endosomal membrane. Thereafter, the viral core particle is transported within the cytosol to the nuclear pore complex via microtubules. After disassembly 
of the core particle inside the basket of the nuclear pore complex [26, 27], the rcDNA form is converted into cccDNA [28]. The cccDNA is then complexed with histone and nonhistone proteins, and can thus be regarded as a stable episomal minichromosome, similar to other episomal viral genomes typical for polyomaviruses and papillomaviruses [29]. A reverse transcription step during genome replication is shared by the viral families Hepadnaviridae and Retroviridae (e.g. HIV), but an integration of the HBV genome within the host cell genome will lead to destruction of its circular DNA genome, in contrast to the linear HIV DNA provirus. As mentioned above, all transcribed viral RNAs from $\mathrm{HBV}$ cccDNA contain a $5^{\prime}$ cap and a $3^{\prime}$ polyA tail structure. Potential splice sites within the hepadnaviral RNAs are suppressed by a posttranslational regulatory element, which also mediates the nuclear export of the RNAs. pgRNA encodes the complete HBV genome including overlength redundancy with additional sequence elements necessary for viral replication [14]. pgRNA is the template for reverse transcription and genome maturation, and also serves for the translation of core protein and polymerase. Replication of hepadnaviruses starts with binding of the viral DNA polymerase ( $\mathrm{Pol}$ ) to a stem-loop structure close to the $5^{\prime}$ end of the pgRNA, called $\varepsilon$ (epsilon) [14]. This reaction induces encapsidation of the whole complex along with core protein into an immature core particle. Reverse transcription starts with the formation of a phosphodiester bond between the hydroxyl residue of a tyrosine in the terminal protein domain of the Pol protein and the first nucleotide of the minus strand. After a complex shift of the nascent minus DNA strand to the $3^{\prime}$ terminal $\varepsilon$, a complete minus DNA strand is transcribed. The template RNA strand degradation by viral RNase $\mathrm{H}$ and the primer shift pave the way to subsequent plus strand DNA synthesis, resulting in a partially double-stranded HBV DNA genome. The HBV polymerase is thereby still attached to a variable $3^{\prime}$ end of the growing plus strand [14].

Budding of HBV is mediated by a multiprotein mechanism, called the 'endosomal sorting complex required for transport' (ESCRT) [30, 31]. The preS-domain of LHBs (17 C-terminal AA of preS1 and $5 \mathrm{~N}$-terminal AA), facing towards the cytoplasm [32, 33], interacts with mature nucleocapsids containing viral rcDNA. Some reports indicate that the cytosolic loop of the Sdomain might also be involved in HBV assembly [3437]. Budding of HBV occurs from an intracellular membrane, and involves ESCRT protein complexes that are also necessary for formation of multivesicular bodies, a

Molecular Virology of HBV and Targets

for Antiviral Intervention special intracellular compartment containing intraluminal vesicles $[38,39]$. Secreted nonenveloped HBV core particles have not been observed in the plasma of chronically $\mathrm{HBV}$-infected patients without anti-HBc [40]. However, secretion of naked cores is a common phenomenon of HBV-producing hepatoma cell lines, e.g. HepG2.2.15 [11, 31, 41, 42], which are mediated by an ESCRT-independent process at the plasma membrane [43].

HBV subviral particle formation begins with translation and integration of the multitransmembrane-spanning S-domain of the three HBV surface proteins at the membrane of the endoplasmic reticulum (ER). Translational modification involves $\mathrm{N}$ - and O-glycosylation [44, 45], but also the formation of intra- and intermolecular disulfide bridges by ER-resident protein disulfide isomerase, connecting the highly conserved free cysteine groups of the S-domain of monomeric HBV surface proteins [46]. This results in assembly of surface protein dimers and, most importantly, formation of the antigenic (a) determinant that is essential for attachment to heparan sulfate proteoglycans and recognition by protective antibodies. Those surface protein dimers are reported to be the building blocks of filamentous structures that will be converted into spheres in an ER-Golgi intermediate compartment, followed by secretion through the classical secretory pathway (fig. 1) [47, 48]. Subviral particles are secreted as $20-\mathrm{nm}$ spheres and filaments with variable lengths but similar diameters.

\section{Therapeutic Intervention of the Replicative Cycle of HBV}

\section{HBV Entry Inhibitors}

Blocking viral infection of host cells at the level of the very early steps of infection, viral binding, and entry of host cells is one of the key goals of antiviral intervention. This can be achieved by either targeting the virus itself or host cell molecules involved in viral binding and entry. Successful vaccination by the HBV vaccine neutralizes $\mathrm{HBV}$ infectivity by targeting the antigenic loop of $\mathrm{HBV}$ surface proteins, necessary for infection. However, full protection (anti-HBs titer $>100 \mathrm{IU} / \mathrm{l}$ ) with this vaccine can only be achieved by an active immune system, and patients with subtle immune suppression (e.g. dialysis patients) suffer from incomplete vaccine response and are poorly protected against $\mathrm{HBV}$ infection. In addition, anti-HBs titers usually show a fast drop during the first year after vaccination [49]. Low anti-HBs titers can protect 
against hepatitis B [50], but are often unable to provide sterilizing immunity after exposure to HBV (e.g. of healthcare workers and sexual partners) as described recently $[51,52]$. Thus, in those cases with missing or incomplete protection against $\mathrm{HBV}$, postexposure prophylaxis relies on passive administration of anti-HBs antibodies (HBIG) isolated from sera of vaccinees. In clinical practice, this is currently given to newborns to prevent perinatal infection from their $\mathrm{HBV}$-infected mothers in combination with active vaccination (for a current review, see Gerlich [this issue, pp. 131-133), and during liver transplantation in combination with nucleos(t)ide analogues (for a current review, see Roche and Samuel [this issue, pp. 196-201]). Since the identification of NTCP [25], a bile salt transporter of hepatocytes, as a high-affinity receptor for $\mathrm{HBV}$, many antiviral drug approaches are currently focused on blocking HBV interaction with this receptor [53-55]. One of the straightforward approaches is the use of myristoylated preS1 peptides from the N-terminal preS1-domain of LHBs. This domain is essentially involved in HBV infection due to high-specific receptor-binding to the NTCP [56]. Interestingly, the antiviral potency of these infection-interfering acylated preS1-lipopetides was characterized in vitro and in vivo long before NTCP was known as a high-affinity receptor for HBV [57-61]. For further details, see the review by Lempp and Urban [this issue, pp. 151-157].

\section{Modulation of HBV cccDNA Pool}

$\mathrm{HBV}$ transcription is maintained from a pool of episomal cccDNA that is associated with histone and nonhistone proteins within the nucleus of the infected hepatocyte (fig. 1) [14, 29]. The cccDNA is very stable and able to endure prolonged times in infected hepatocytes of the liver even after antiviral treatment with immunological control of the infection (for review, see [62]). HBV cccDNA stability itself, but also viral gene expression, is highly dependent on epigenetic factors like posttranslational modification of bound histones (e.g. acetylation and methylation) and alterations of cccDNA itself (e.g. methylation) [29]. Specific control of those factors, responsible for stability or even transcriptional repression of cccDNA, to prevent viral reactivation after stopping antiviral therapy with nucleos(t)ide analogues or during severe immune suppression would be a hallmark for future antiviral therapies [29]. Specific epigenetic modulation of HBV cccDNA versus the host genome will be difficult to achieve, but epigenetic modification of cccDNA has been reported as an essential factor of the antiviral effect of interferon- $\alpha$ in vitro and in vivo [63].

\section{Inhibitors of Reverse Transcription}

Based on the success of antiviral intervention of viral polymerases with nucleoside analogues in the case of HIV and herpesviruses, five nucleos(t)ide analogues have finally been approved for antiviral treatment of HBV infection. The first drug, lamivudine (a pyrimidine L-nucleoside) demonstrated antiviral activity against $\mathrm{HBV}$ polymerase in vitro [64] and in vivo [65, 66]. Current L-nucleosides also include telbivudine, emtricitabine, clevudine, and torcitabine, but only telbivudine has been licensed so far. The other licensed drugs are adefovir dipivoxil and tenofovir disoproxil fumarate, which are grouped into nucleoside phosphonate prodrugs (nucleotide analogues), and entecavir functioning as a guanosine analogue.

All nucleos(t)ide analogues have the ability to reduce $\mathrm{HBV}$ viral load in the serum and improve clinical signs of $\mathrm{HBV}$-associated disease, like serum ALT levels. However, entecavir and tenofovir have proven to be the most potent drugs in this respect, with their high genetic barrier against emerging antiviral resistance and virologic response rates in lowering HBV viral load, often below the limit of detection, in the serum of patients with chronic hepatitis B $[67,68]$.

All inhibitors of reverse transcription inhibit genome maturation, which is a precondition of envelopment and secretion of infectious viral particles (fig. 1). This block, however, is not curative in the case of HBV and requires ongoing treatment, possibly lifelong if no additional defense mechanisms are active. In addition, those drugs are unable to interfere with transcription of the HBV genome and thus cannot inhibit synthesis and secretion of $\mathrm{HBeAg}$ and $\mathrm{HBsAg}$, resulting in persistent antigenemia. Furthermore, reverse transcription of HBV takes place after infection has been already been established with the formation of HBV cccDNA in the nucleus of infected hepatocytes. Therefore, nucleos(t)ide inhibitors are unable to prevent (re)infection of cells. This is in contrast to HIV, where reverse transcription of the viral RNA genome has to take place ultimately after infection in the cytoplasm of the cell before integration of the proviral DNA into the host genome.

\section{Core Assembly Inhibitors}

Several nonnucleosidic inhibitors of HBV capsid assembly have been characterized that hamper proper assembly of HBV core particles and thus block reverse transcription of HBV (fig. 1) [69-71]. Although results in vitro and in animal models with these drugs have been very promising, reliable clinical studies have not been reported. 


\section{Acknowledgements}

The authors thank Wolfram H. Gerlich, Rolf Kaiser, and Lutz Gürtler for critical reading of the manuscript. The work of the authors was supported by grants from the Deutsche Forschungsge- meinschaft (German Research Foundation; DFG), the German Federal Ministry of Education and Research (BMBF), the Germany Federal Ministry of Health, The German Centre for Infection Research (DZIF), the Universitaetsklinikum Giessen and Marburg $\mathrm{GmbH}$, and the von Behring-Roentgen Foundation, Germany.

\section{References}

1 Ott JJ, Stevens GA, Groeger J, Wiersma ST: Global epidemiology of hepatitis B virus infection: new estimates of age-specific $\mathrm{HBsAg}$ seroprevalence and endemicity. Vaccine 2012;30:2212-2219.

2 Lavanchy D: Viral hepatitis: global goals for vaccination. J Clin Virol 2012;55:296-302.

-3 El-Serag HB: Epidemiology of viral hepatitis and hepatocellular carcinoma. Gastroenterology 2012;142:1264-1273.e1.

4 International Committee on Taxonomy of Viruses (ITCV): Virus taxonomy. 2012. http://www.ictvonline.org/virusTaxonomy. asp?version=2012 (accessed February 10, 2014).

5 Lanford RE, Chavez D, Brasky KM, Burns RB 3rd, Rico-Hesse R: Isolation of a hepadnavirus from the woolly monkey, a new world primate. Proc Natl Acad Sci USA 1998;95:57575761.

-6 Drexler JF, Geipel A, König A, Corman VM, van Riel D, Leijten LM, Bremer CM, Rasche A, Cottontail VM, Maganga GD, Schlegel M, Müller MA, Adam A, Klose SM, Carneiro AJ, Stocker A, Franke CR, Gloza-Rausch F, Geyer J, Annan A, Adu-Sarkodie Y, Oppong S, Binger T, Vallo P, Tschapka M, Ulrich RG, Gerlich WH, Leroy E, Kuiken T, Glebe D, Drosten C: Bats carry pathogenic hepadnaviruses antigenically related to hepatitis B virus and capable of infecting human hepatocytes. Proc Natl Acad Sci USA 2013;110:16151-16156.

-7 He B, Fan Q, Yang F, Hu T, Qiu W, Feng Y, Li Z, Li Y, Zhang F, Guo H, Zou X, Tu C: Hepatitis virus in long-fingered bats, Myanmar. Emerg Infect Dis 2013;19:638-640.

-8 Seitz S, Urban S, Antoni C, Böttcher B: Cryoelectron microscopy of hepatitis $\mathrm{B}$ virions reveals variability in envelope capsid interactions. EMBO J 2007;26:4160-4167.

9 Dryden KA, Wieland SF, Whitten-Bauer C, Gerin JL, Chisari FV, Yeager M: Native hepatitis $B$ virions and capsids visualized by electron cryomicroscopy. Mol Cell 2006;22:843-850.

10 Kann M, Gerlich WH: Effect of core protein phosphorylation by protein kinase $\mathrm{C}$ on encapsidation of RNA within core particles of hepatitis B virus. J Virol 1994;68:7993-8000.

$\checkmark 11$ Wittkop L, Schwarz A, Cassany A, GrunBernhard S, Delaleau M, Rabe B, Cazenave C, Gerlich W, Glebe D, Kann M: Inhibition of protein kinase $\mathrm{C}$ phosphorylation of hepatitis $B$ virus capsids inhibits virion formation and causes intracellular capsid accumulation. Cell Microbiol 2010;12:962-975.
12 Kau JH, Ting LP: Phosphorylation of the core protein of hepatitis $B$ virus by a 46-kilodalton serine kinase. J Virol 1998;72:3796-3803.

13 Landers TA, Greenberg HB, Robinson WS: Structure of hepatitis B Dane particle DNA and nature of the endogenous DNA polymerase reaction. J Virol 1977;23:368-376.

14 Beck J, Nassal M: Hepatitis B virus replication. World J Gastroenterol 2007;13:48-64.

15 Heermann KH, Goldmann U, Schwartz W, Seyffarth T, Baumgarten H, Gerlich WH: Large surface proteins of hepatitis $B$ virus containing the pre-s sequence. J Virol 1984; 52:396-402.

$>16$ Glebe D, Bremer CM: The molecular virology of hepatitis B virus. Semin Liver Dis 2013;33: 103-112.

17 Glebe D, Urban S: Viral and cellular determinants involved in hepadnaviral entry. World J Gastroenterol 2007;13:22-38.

18 Garcia PD, Ou JH, Rutter WJ, Walter P: Targeting of the hepatitis $\mathrm{B}$ virus precore protein to the endoplasmic reticulum membrane: after signal peptide cleavage translocation can be aborted and the product released into the cytoplasm. J Cell Biol 1988;106:1093-1104.

19 Magnius LO, Espmark A: A new antigen complex co-occurring with Australia antigen. Acta Pathol Microbiol Scand B Microbiol Immunol 1972;80:335-337.

20 Kew MC: Hepatitis B virus X protein in the pathogenesis of hepatitis $B$ virus-induced hepatocellular carcinoma. J Gastroenterol Hepatol 2011;26(suppl 1):144-152.

21 Lucifora J, Arzberger S, Durantel D, Belloni L, Strubin M, Levrero M, Zoulim F, Hantz O, Protzer U: Hepatitis B virus X protein is essential to initiate and maintain virus replication after infection. J Hepatol 2011;55:9961003.

22 Leistner CM, Grün-Bernhard S, Glebe D: Role of glycosaminoglycans for binding and infection of hepatitis B virus. Cell Microbiol 2008; 10:122-133.

23 Sureau C, Salisse J: A conformational heparan sulfate-binding site essential to infectivity overlaps with the conserved hepatitis B virus a-determinant. Hepatology 2012.

24 Schulze A, Gripon P, Urban S: Hepatitis B virus infection initiates with a large surface protein-dependent binding to heparan sulfate proteoglycans. Hepatology 2007; 46:17591768 .
25 Yan $\mathrm{H}$, Zhong G, Xu G, He W, Jing Z, Gao Z, Huang Y, Qi Y, Peng B, Wang H, Fu L, Song M, Chen P, Gao W, Ren B, Sun Y, Cai T, Feng $\mathrm{X}$, Sui J, Li W: Sodium taurocholate cotransporting polypeptide is a functional receptor for human hepatitis B and D virus. eLife 2012; 1:e00049.

26 Schmitz A, Schwarz A, Foss M, Zhou L, Rabe B, Hoellenriegel J, Stoeber M, Pante N, Kann M: Nucleoporin 153 arrests the nuclear import of hepatitis B virus capsids in the nuclear basket. PLoS Pathog 2010;6:e1000741.

27 Rabe B, Delaleau M, Bischof A, Foss M, Sominskaya I, Pumpens P, Cazenave C, Castroviejo M, Kann M: Nuclear entry of hepatitis $B$ virus capsids involves disintegration to protein dimers followed by nuclear reassociation to capsids. PLoS Pathog 2009;5:e1000563.

28 Köck J, Rösler C, Zhang JJ, Blum HE, Nassal M, Thoma C: Generation of covalently closed circular DNA of hepatitis B viruses via intracellular recycling is regulated in a virus specific manner. PLoS Pathog 2010;6:e1001082.

29 Levrero M, Pollicino T, Petersen J, Belloni L, Raimondo G, Dandri M: Control of cccDNA function in hepatitis $B$ virus infection. J Hepatol 2009;51:581-592.

30 Lambert C, Döring T, Prange R: Hepatitis B virus maturation is sensitive to functional inhibition of ESCRT III, Vps4, and gamma 2-adaptin. J Virol 2007;81:9050-9060.

31 Watanabe T, Sorensen EM, Naito A, Schott M, Kim S, Ahlquist P: Involvement of host cellular multivesicular body functions in hepatitis B virus budding. Proc Natl Acad Sci USA 2007;104:10205-10210.

32 Gerelsaikhan T, Tavis JE, Bruss V: Hepatitis B virus nucleocapsid envelopment does not occur without genomic DNA synthesis. J Virol

1996;70:4269-4274.
33 Bruss V: A short linear sequence in the pre-S domain of the large hepatitis $B$ virus envelope protein required for virion formation. J Virol 1997;71:9350-9357.

34 Tan WS, Dyson MR, Murray K: Two distinct segments of the hepatitis B virus surface antigen contribute synergistically to its association with the viral core particles. J Mol Biol 1999;286:797-808.

35 Löffler-Mary H, Dumortier J, Klentsch-Zimmer C, Prange R: Hepatitis B virus assembly is sensitive to changes in the cytosolic S loop of the envelope proteins. Virology 2000;270: 358-367.
Molecular Virology of HBV and Targets for Antiviral Intervention 
36 Blanchet M, Sureau C: Analysis of the cytosolic domains of the hepatitis $B$ virus envelope proteins for their function in viral particle assembly and infectivity. J Virol 2006;80: 11935-11945.

- 37 Poisson F, Severac A, Hourioux C, Goudeau A, Roingeard P: Both pre-S1 and S domains of hepatitis B virus envelope proteins interact with the core particle. Virology 1997;228: 115-120.

- 38 Guizetti J, Schermelleh L, Mantler J, Maar S, Poser I, Leonhardt H, Müller-Reichert T, Gerlich DW: Cortical constriction during abscission involves helices of ESCRT III dependent filaments. Science 2011;331:1616-1620.

-39 Guizetti J, Gerlich DW: ESRT-III polymers in membrane neck constriction. Trends Cell Biol 2012;22:133-140.

-40 Possehl C, Repp R, Heermann KH, Korec E, Uy A, Gerlich WH: Absence of free core antigen in anti- $\mathrm{HBc}$ negative viremic hepatitis $\mathrm{B}$ carriers. Arch Virol Suppl 1992;4:39-41.

41 Pairan A, Bruss V: Functional surfaces of the hepatitis B virus capsid. J Virol 2009;83: 11616-11623.

42 Sun D, Nassal M: Stable HepG2- and Huh7based human hepatoma cell lines for efficient regulated expression of infectious hepatitis $B$ virus. J Hepatol 2006;45:636-645.

43 Bardens A, Doring T, Stieler J, Prange R: Alix regulates egress of hepatitis $B$ virus naked capsid particles in an ESCRT-independent manner. Cell Microbiol 2011;13:602-619.

44 Schmitt S, Glebe D, Tolle TK, Lochnit G, Linder D, Geyer R, Gerlich WH: Structure of pre-S2 $\mathrm{N}$ - and O-linked glycans in surface proteins from different genotypes of hepatitis B virus. J Gen Virol 2004;85:2045-2053.

45 Schmitt S, Glebe D, Alving K, Tolle TK, Linder M, Geyer H, Linder D, Peter-Katalinic J, Gerlich WH, Geyer R: Analysis of the pre-S2 $\mathrm{N}$ - and O-linked glycans of the $\mathrm{M}$ surface protein from human hepatitis B virus. J Biol Chem 1999;274:11945-11957.

46 Huovila AP, Eder AM, Fuller SD: Hepatitis B surface antigen assembles in a post-ER, preGolgi compartment. J Cell Biol 1992;118: 1305-1320.

47 Patient R, Hourioux C, Sizaret PY, Trassard S, Sureau C, Roingeard P: Hepatitis B virus subviral envelope particle morphogenesis and intracellular trafficking. J Virol 2007;81:38423851.

-48 Patient R, Hourioux C, Roingeard P: Morphogenesis of hepatitis $B$ virus and its subviral envelope particles. Cell Microbiol 2009;11: 1561-1570.

49 Jilg W, Schmidt M, Deinhardt F: Decline of anti-HBs after hepatitis $B$ vaccination and timing of revaccination. Lancet 1990;335: 173-174.

50 McMahon BJ, Bruden DL, Petersen KM, Bulkow LR, Parkinson AJ, Nainan O, Khristova M, Zanis C, Peters H, Margolis HS: Antibody levels and protection after hepatitis $\mathrm{B}$ vaccination: results of a 15-year follow-up. Ann Intern Med 2005;142:333-341.
51 Werner JM, Abdalla A, Gara N, Ghany MG, Rehermann B: The hepatitis $\mathrm{B}$ vaccine protects re-exposed health care workers, but does not provide sterilizing immunity. Gastroenterology 2013;145:1026-1034.

52 Stramer SL, Wend U, Candotti D, Foster GA, Hollinger FB, Dodd RY, Allain JP, Gerlich W: Nucleic acid testing to detect HBV infection in blood donors. N Engl J Med 2011;364:236247.

53 Watashi K, Sluder A, Daito T, Matsunaga S, Ryo A, Nagamori S, Iwamoto M, Nakajima S, Tsukuda S, Borroto-Esoda K, Sugiyama M, Tanaka Y, Kanai Y, Kusuhara H, Mizokami M, Wakita T: Cyclosporin A and its analogs inhibit hepatitis $B$ virus entry into cultured hepatocytes through targeting a membrane transporter NTCP. Hepatology 2013, Epub ahead of print.

54 Nkongolo S, Ni Y, Lempp FA, Kaufman C, Lindner T, Esser-Nobis K, Lohmann V, Mier W, Mehrle S, Urban S: Cyclosporin A inhibits hepatitis B and hepatitis D virus entry by cyclophilin-independent interference with the NTCP receptor. J Hepatol 2014;60:723-731.

55 Iwamoto M, Watashi K, Tsukuda S, Aly HH, Fukasawa M, Fujimoto A, Suzuki R, Aizaki H, Ito T, Koiwai O, Kusuhara H, Wakita T: Evaluation and identification of hepatitis $\mathrm{B}$ virus entry inhibitors using HepG2 cells overexpressing a membrane transporter NTCP. Biochem Biophys Res Commun 2014;443:808813.

56 Volz T, Allweiss L, Ben MM, Warlich M, Lohse AW, Pollok JM, Alexandrov A, Urban S, Petersen J, Lutgehetmann M, Dandri M: The entry inhibitor Myrcludex-B efficiently blocks intrahepatic virus spreading in humanized mice previously infected with hepatitis B virus. J Hepatol 2013;58:861-867.

57 Meier A, Mehrle S, Weiss TS, Mier W, Urban $S$ : Myristoylated preS1-domain of the hepatitis B virus L-protein mediates specific binding to differentiated hepatocytes. Hepatology 2013;58:31-42.

58 Glebe D, Urban S, Knoop EV, Cag N, Krass P, Grun S, Bulavaite A, Sasnauskas K, Gerlich WH: Mapping of the hepatitis B virus attachment site by use of infection-inhibiting preS1 lipopeptides and tupaia hepatocytes. Gastroenterology 2005;129:234-245.

59 Engelke M, Mills K, Seitz S, Simon P, Gripon P, Schnolzer M, Urban S: Characterization of a hepatitis $B$ and hepatitis delta virus receptor binding site. Hepatology 2006;43:750-760.

60 Gripon P, Cannie I, Urban S: Efficient inhibition of hepatitis B virus infection by acylated peptides derived from the large viral surface protein. J Virol 2005;79:1613-1622.

61 Petersen J, Dandri M, Mier W, Luetgehetmann M, Volz T, von Weizsaecker F, Haberkorn U, Fischer L, Pollok J-M, Erbes B, Seitz $S$, Urban S: Prevention of hepatitis B virus infection in vivo by entry inhibitors derived from the large envelope protein. Nat Biotechnol 2008;26:335-341.
62 Zoulim F: New insight on hepatitis B virus persistence from the study of intrahepatic viral cccDNA. J Hepatol 2005;42:302-308.

63 Belloni L, Allweiss L, Guerrieri F, Pediconi N, Volz T, Pollicino T, Petersen J, Raimondo G, Dandri M, Levrero M: IFN-alpha inhibits HBV transcription and replication in cell culture and in humanized mice by targeting the epigenetic regulation of the nuclear cccDNA minichromosome. J Clin Invest 2012;122: 529-537.

64 Doong SL, Tsai CH, Schinazi RF, Liotta DC, Cheng YC: Inhibition of the replication of hepatitis B virus in vitro by $2^{\prime}, 3^{\prime}$-dideoxy- $3^{\prime}$ thiacytidine and related analogues. Proc Natl Acad Sci USA 1991;88:8495-8499.

65 Dienstag JL, Perrillo RP, Schiff ER, Bartholomew M, Vicary C, Rubin M: A preliminary trial of lamivudine for chronic hepatitis B infection. N Engl J Med 1995;333:16571661.

66 Benhamou Y, Dohin E, Lunel-Fabiani F, Poynard T, Huraux JM, Katlama C, Opolon P, Gentilini M: Efficacy of lamivudine on replication of hepatitis B virus in $\mathrm{HIV}$-infected patients. Lancet 1995;345:396-397.

67 Marcellin P, Gane E, Buti M, Afdhal N, Sievert W, Jacobson IM, Washington MK, Germanidis G, Flaherty JF, Schall RA, Bornstein JRD, Kitrinos KM, Subramanian GM, McHutchison JG, Heathcote EJ: Regression of cirrhosis during treatment with tenofovir disoproxil fumarate for chronic hepatitis B: A 5-year open-label follow-up study. Lancet 2013;381: 468-475.

68 Tenney DJ, Rose RE, Baldick CJ, Pokornowski KA, Eggers BJ, Fang J, Wichroski MJ, Xu D, Yang J, Wilber RB, Colonno RJ: Long-term monitoring shows hepatitis $B$ virus resistance to entecavir in nucleoside-naive patients is rare through 5 years of therapy. Hepatology 2009;49:1503-1514.

69 Deres K, Schröder CH, Paessens A, Goldmann S, Hacker HJ, Weber O, Kramer T, Niewohner U, Pleiss U, Stoltefuss J, Graef E, Koletzki D, Masantschek RNA, Reimann A, Jaeger R, Gross R, Beckermann B, Schlemmer $\mathrm{KH}$, Haebich D, Rübsamen-Waigmann $\mathrm{H}$ : Inhibition of hepatitis B virus replication by drug-induced depletion of nucleocapsids. Science 2003;299:893-896.

70 Wang XY, Wei ZM, Wu GY, Wang JH, Zhang YJ, Li J, Zhang HH, Xie XW, Wang X, Wang ZH, Wei L, Wang Y, Chen HS: In vitro inhibition of HBV replication by a novel compound, GLS4, and its efficacy against adefovir-dipivoxil-resistant HBV mutations. Antivir Ther 2012;17:793-803.

71 Weber O, Schlemmer KH, Hartmann E, Hagelschur I, Paessens A, Graef E, Deres K, Goldmann S, Niewoehner U, Stoltefuss J, Haebich D, Ruebsamen-Waigmann H, Wohlfeil S: Inhibition of human hepatitis B virus (HBV) by a novel non-nucleosidic compound in a transgenic mouse model. Antiviral Res 2002;54:69-78 